\title{
Critical thinking skills in midwifery practice: Development of a self-assessment tool for students.
}

\section{Abstract}

Objective: Develop and test a tool designed for use by pre-registration midwifery students to self-appraise their critical thinking in practice.

Design: A descriptive cohort design was used.

Participants: All students $(n=164)$ enrolled in a three-year Bachelor of Midwifery program in Queensland, Australia.

Methods: The staged model for tool development involved item generation, mapping draft items to critical thinking concepts and expert review to test content validity, pilot testing of the tool to a convenience sample of students, and psychometric testing. Students ( $n=126,76.8 \%$ response rate) provided demographic details, completed the new tool, and five questions from the Motivated Strategies for Learning Questionnaire (MSLQ) via an online platform or paper version.

Findings: A high content validity index score of 0.97 was achieved through expert review. Construct validity via factor analysis revealed four factors: seeks information, reflects on practice, facilitates shared decision making, and evaluates practice. The mean total score for the tool was 124.98 (SD =12.58). Total and subscale scores correlated significantly. The scale achieved good internal reliability with a Cronbach's alpha coefficient of .92. Concurrent validity with the MSLQ subscale was .35 ( $p$ $<.001)$.

Conclusion: This study established the reliability and validity of the CACTiM student version for use by pre-registration midwifery students to self-assess critical thinking in practice.

Implications for practice: Critical thinking skills are vital for safe and effective midwifery practice. Students' assessment of their critical thinking development throughout their pre-registration programme makes these skills explicit, and could guide teaching innovation to address identified deficits. The availability of a reliable and valid tool assists research into the development of critical thinking in education and practice. 
Key words: Critical thinking, pre-registration, midwifery, students, reflection, selfappraisal

\section{Highlights}

- Strategies to develop students' critical thinking may not be explicit in curricula.

- Students need guidance to develop their critical thinking in practice.

- There are few freely available standardised tools on critical thinking.

- CACTiM was found to be a valid and reliable tool for use by midwifery students. 


\section{Critical thinking skills in midwifery practice: Development of a self-assessment tool for students.}

\section{Introduction}

Critical thinking involves a reflective process in making judicious purposeful judgements using cognitive processes of analysis, interpretation, evaluation, inference, explanation, and reflection (Facione, 1990; Hendricson, et al., 2006). As midwives welcome increasing autonomy in their practice, their need to possess welldeveloped critical thinking skills also increases. Critical thinking in practice informs professional judgement and decision making, enabling midwives to provide flexible, woman centred, holistic, evidence-based care whilst incorporating women's choice (Lake and Mclnnes, 2012). Adding to this complexity is the ambiguity regarding 'best practice' in many practice situations (Scholes et al., 2012), and the need to contexualise any available evidence to an individual woman's circumstances.

Decision-making can be viewed as key to quality professional practice (Thompson and Dowding, 2002), and critical thinking is an essential cognitive process in reaching efficacious clinical decisions. Yet, best practice teaching strategies to develop student's problem solving and critical thinking skills remain uncertain (Hendricson, et al., 2006; Carter, et al., 2016). Facione (1990) proposed that a coordinated approach to curricula, pedagogy, and assessment strategies needs to focus on developing the cognitive skills and habits of inquiry associated with critical thinking.

Whilst the need to develop critical thinking skills of pre-registration midwifery students is clear, the measurement of this development is not. A systematic review of the literature on tools used to measure the development of critical thinking in midwifery and nursing undergraduate students discovered an absence of tools for specific use in midwifery practice (Carter, et al., 2015). A further review which evaluated the efficacy of teaching methods used to develop critical thinking skills in midwifery and nursing undergraduate students found inconsistencies (Carter, et al., 2016). Of the twenty-eight studies reviewed, seventeen identified strategies that increased critical thinking, while nine studies found no increases, and two reported unexplained decreases in CT when using similar educational interventions. While 
these inconsistencies could be attributed to flaws in methodology and outcome measures, both reviews recommended the development of discipline-specific instruments to measure critical thinking, particularly tools that measure the application of critical thinking in midwifery practice (Carter, et al., 2015; Carter, et al., 2016).

Critical thinking also requires the development of critical awareness and reflectivity (Dearnley and Meddings, 2007), which enhance learning and achievement through improved self-efficacy (Crede' and Phillips, 2011). The concept that students benefit from engagement in self-assessment and monitoring is commonly recognised within the adult learning literature (Sadler, 2005). Effective self-assessment requires students to deconstruct an event, make a judgement, reflect on their understanding of the situation and evaluate appropriate responses, thereby cultivating skills required for professional practice (Hendricson, et al., 2006; Mould, et al., 2011).

Learning to evaluate one's practice and competence is essential for midwifery students as they prepare to become autonomous practitioners with increasing accountability for decision-making (Kitson-Reynolds and Rogers, 2013). However, teaching practices in most midwifery pre-registration programs tend to focus on the attainment and assessment of theoretical knowledge and clinical skill development. Limited attention is given to strategies that facilitate and measure cognitive skill development in practice (Lake and Mclnnes, 2012).

Given the importance of developing and measuring critical thinking in midwifery practice, and the value of utilising self-assessment by students, the current study reports on the development and testing of a tool designed for pre-registration midwifery students to self-assess their critical thinking skills in practice.

\section{Research Questions}

1. To what extent is the draft tool reliable and valid for self-assessment of critical thinking in practice by pre-registration midwifery students?

2. What is the level of students' critical thinking in practice?

\section{Methods}

Design 
A staged model was used for tool development and tested using a descriptive cohort design.

\section{Setting}

The Bachelor of Midwifery program at XXXX University reflects a social emancipatory model of a transformative education philosophy. Transformational learning involves contextualised learning where students are enabled to claim and develop their own ways of knowing, critically assessing themselves and their practice (McAllister, 2005, McAllister, et al., 2007).

In line with the Australian Qualifications Framework (Level 7 - Bachelor Degree) one of the core aims within the Bachelor of Midwifery program is to facilitate the development of student's cognitive and creative skills to exercise critical thinking and judgement in identifying and solving problems with intellectual independence (Australian Qualifications Framework Council, 2013).

The clinical component of the three-year Bachelor of Midwifery program, requires students to be placed at one primary site for the duration of their degree. Students complete around 1,800 hours of clinical practice, in a continuous model rather than traditional block placements. Students' clinical learning is facilitated by midwifery preceptors (working in hospitals or private midwifery practices) supported by university-employed onsite practice lecturers.

\section{Participants}

Inclusion criteria were students $(n=164)$ enrolled in any year of the Bachelor of Midwifery program who had completed at least one semester of clinical placement. All potential students had undertaken clinical placements ranging from 280 hours $\left(1^{\text {st }}\right.$ year) up to 1,800 hours ( $3^{\text {rd }}$ year). As the main purpose of this study was to test the newly developed tool it was considered important to include all students to elicit a range of practice levels and potential critical thinking abilities.

\section{Sample size calculation}

Generally, in tool development research, a recommended minimum participant to item ratio of 5:1 is acceptable (Gorsuch, 1983; Hatcher, 1994), with a minimum of 100 subjects, regardless of the number of items (Gorsuch, 1983). Our sample size 
calculation recommended a sample of 116 in order to achieve a $95 \%$ confidence level with a $5 \%$ margin of error (Raosoft Inc, 2004).

\section{Ethical considerations}

Ethical approval was attained through the Human Research Ethics Committee of XXXX University. Students were informed about the aim of the study, and that completion of the survey implied consent. Students were also informed that participation was voluntary; and results would be reported in group aggregate form.

\section{Instrument Development}

We followed a staged model for tool development that involved item generation; mapping of draft items to critical thinking concepts to test content validity and expert review; pilot testing of the tool and items to a convenience sample of students; and psychometric testing (DeVellis 2017).

\section{Literature review and generation of item pool}

The generation of items occurred firstly from an extensive review of the literature to establish relevant conceptual domains and content. An examination of the National Competency Standards for the Midwife (ANMC, 2006) was also undertaken. We also developed items that reflected midwifery philosophy and practice based on a midwife-woman partnership where informed choice and shared decision making is fundamental to care (Australian College of Midwives, 2011; Renfrew et al., 2014).

\section{Content validity}

A two stage process was used to establish content validity. Firstly, draft items were reviewed by two experienced midwifery researchers (PhD qualified, extensive publication record, PhD supervisors) and an experienced midwifery practitioner (more than 10 years providing midwifery continuity of care). Secondly, a process of mapping draft items to the consensus definition of critical thinking in nursing developed by Scheffer and Rubenfeld (2000) occurred. This process aimed to ensure that all core concepts of critical thinking were represented. The mapping of items was then verified by the two midwifery researchers. An example of mapping for four of the 25 items is provided in Table 1. The wording of items was further refined 
in minor ways according to feedback received. Further enhancement of item wording and development of new items occurred following mapping to ensure all domains of critical thinking were addressed.

A decision was made to use a six point Likert scale of $1=$ strongly disagree to $6=$ strongly agree (Stage 3). The use of a six-point response option prevents equivocation (DeVellis, 2017). 
Table 1: Example of mapping items to habit of mind and skills in consensus definition of critical thinking in nursing

\begin{tabular}{|c|c|c|c|c|}
\hline \multirow{2}{*}{$\begin{array}{l}\text { Habits of Mind and Skills of } \\
\text { Critical Thinking in Nursing } \\
\text { Scheffer and Rubenfeld (2000). }\end{array}$} & \multicolumn{4}{|c|}{ Examples of four items from the draft tool } \\
\hline & & & & \\
\hline $\begin{array}{l}\text { Habits of Mind (Affective } \\
\text { Components) }\end{array}$ & $\begin{array}{l}\text { I often instinctively } \\
\text { know what type of } \\
\text { care is right for a } \\
\text { woman }\end{array}$ & $\begin{array}{l}\text { If problems arise when } \\
\text { caring for a woman I } \\
\text { always try to seek the root } \\
\text { cause }\end{array}$ & $\begin{array}{l}\text { I question the 'unwritten } \\
\text { rules' in midwifery } \\
\text { practice that are not } \\
\text { evidence-based }\end{array}$ & $\begin{array}{l}\text { I can provide the rationale } \\
\text { for following (or departing } \\
\text { from) established guidelines } \\
\text { and policies }\end{array}$ \\
\hline Confidence & & & $\mathbf{x}$ & $\mathbf{x}$ \\
\hline Contextual perspective & $\mathbf{x}$ & & & $\mathbf{x}$ \\
\hline Creativity & $\mathbf{x}$ & & & \\
\hline Flexibility & & & & \\
\hline Inquisitiveness & & $\mathbf{x}$ & & \\
\hline Intellectual Integrity & & & & \\
\hline Intuition & $\mathbf{x}$ & $\mathbf{x}$ & & \\
\hline Open-mindedness & & & & \\
\hline Perseverance & & $\mathbf{x}$ & $\mathbf{x}$ & \\
\hline Reflection & & $\mathbf{x}$ & & \\
\hline
\end{tabular}


Habits of Mind and Skills of

Examples of four items from the draft tool

Critical Thinking in Nursing

Scheffer and Rubenfeld (2000).

\begin{tabular}{|c|c|c|c|c|}
\hline $\begin{array}{l}\text { Habits of Mind (Affective } \\
\text { Components) }\end{array}$ & $\begin{array}{l}\text { I often instinctively } \\
\text { know what type of } \\
\text { care is right for a } \\
\text { woman }\end{array}$ & $\begin{array}{l}\text { If problems arise when } \\
\text { caring for a woman I } \\
\text { always try to seek the root } \\
\text { cause }\end{array}$ & $\begin{array}{l}\text { I question the 'unwritten } \\
\text { rules' in midwifery } \\
\text { practice that are not } \\
\text { evidence-based }\end{array}$ & $\begin{array}{l}\text { I can provide the rationale } \\
\text { for following (or departing } \\
\text { from) established guidelines } \\
\text { and policies }\end{array}$ \\
\hline
\end{tabular}

\section{Applying Standards}

$\mathbf{X}$

\section{Discriminating}

\section{Information Seeking}

\section{Logical Reasoning}

Predicting

Transforming Knowledge
X
$\mathbf{X}$

$\mathbf{X}$ 


\section{Expert Review}

Scale items were reviewed by a panel of experts to establish content validity. The panel consisted of eleven members, nine of whom were midwifery academics/practice lecturers and two clinicians undertaking doctoral studies. There is some controversy in the literature regarding the number of experts required to undertake a review, with recommended numbers ranging between 2-20 (Gable and Wolf, 1993; Walz et al., 1991). Rather than focus on the number of experts, we chose experts with the desired expertise and diversity of knowledge (Grant and Davis 1997). As the tool aimed to measure critical thinking in midwifery practice, our experts had a variety of clinical experiences gained over a considerable time (8-31 years), as well as academic expertise (1-15 years) and understanding of critical thinking concepts.

To ensure congruity between concepts and item content domains, panel members were provided with a verbal overview of the conceptual basis for the instrument (Grant and Davis, 1997). This discussion outlined a definition of critical thinking and translation of critical thinking into midwifery practice. The panel were also briefed on the purpose of the study, and provided with instructions regarding completion of the expert review survey and the Content Validity Index (CVI). The expert panel members were asked to rate the relevance of each item in measuring critical thinking in midwifery practice on a four point Likert scale of $1=$ not at all relevant to $4=$ highly relevant (DeVellis 2017). Panel members also evaluated the clarity and conciseness of each item and suggest alternative wording if necessary.

\section{Results of Expert Review}

The CVI was calculated from the percentage of total items judged to be valid by receiving a score of 3 or 4 (Grant and Davis, 1997). For a panel of 10 or more experts a CVI above 0.73 was considered valid (Lynn, 1986). In the current study, item CVI scores ranged from 0.82 to 1 , with all of the 25 items achieving a CVI above 0.73 , therefore no items were removed. The CVI score for the total scale (average item CVI) was 0.97 , representing good content validity. All written comments related to clarity of items were analysed. Any suggested alternative wording proposed by an expert was considered by the researchers and the item revised. Following the expert review, 
the draft tool had 25 items within the two domains of "habits of mind" and "skills" in critical thinking, and was ready for pilot testing.

\section{Construct validity}

Inclusion of other validated scales measuring similar concepts can be used to test construct validity (DeVellis, 2017). A literature search related to critical thinking identified the Motivated Strategies for Learning Questionnaire (MSLQ) (OERI/DE, 1991). The MSLQ is an 81-item self-report instrument comprising of fifteen subscales that assess both student motivation to engage with learning, and learning strategies used (Credé and Phillips, 2011). The subscales can be used collectively or singularly. We selected and administered a MSLQ subscale of five items on critical thinking with the authors' permission. These items relate to applying previous knowledge to new situations in order to solve problems, reach decisions, or make critical evaluations with respect to standards of excellence (Credé and Phillips, 2011). This sub-scale has a satisfactory Cronbach's Alpha of 0.80 (Garcia Duncan and McKeachie, 2005).

\section{Survey and psychometric testing}

Procedure for data collection

Paper copies of the survey and information sheet were distributed to students during tutorial sessions of clinical courses during October 2016. A link to the online version of the survey and information sheet was also posted on clinical course sites for students who did not attend the tutorial. Students were requested to complete the tool and assess their own critical thinking skills in practice. Consent was implied through completion of the survey. Completed paper surveys were placed in a sealed envelope. Students were informed that the survey was anonymous

\section{Approach to Analysis}

Data were analyzed using the Statistical Package for the Social Sciences (SPSS) 24.0 (2016) personal computer version. The Cronbach's alpha coefficient was used to assess internal consistency. The tool was analysed according to inter-item correlation, and principal components analysis (PCA) with varimax rotation and exploratory factor analysis. An evaluation of each subscale extracted from the factor 
analysis was conducted. Total and subscale scores were calculated. Correlations between factor scores and total scale score as well as the item-subscale correlations were assessed using Pearson's correlation. Descriptive statistics were used to analyse characteristics of the sample. An alpha level of 0.05 was used for all statistical tests.

\section{Findings}

Participant Characteristics/Sample

The sample consisted of 126 (out of 164) students giving a response rate of $76.8 \%$. The mean age of participants was 30.4 years ( $S D=8.4$, range 18 and 58 years). Nearly forty percent of respondents were first year students $(38.1 \%), 34.9 \%$ were in second year and $27 \%$ in third year. Almost thirty percent held a previous Bachelor's Degree (29.4\%) and 9.5\% had postgraduate qualifications in disciplines other than midwifery.

\section{Findings of item analysis}

All items had positive item-total correlation coefficients (Table 2). Corrected itemtotal correlations ranged between 0.31 and 0.69 , therefore no items were removed (DeVellis, 2017).

\section{Findings of construct validity}

The scale demonstrated good sampling adequacy for factor analysis. The KaiserMeyer-Olkin (KMO) value was 0.87 , exceeding the recommended value of 0.6 (Kaiser, 1974) and Bartlett's Test of Sphericity reached statistical significance (Chisquare $=1658.753, \mathrm{p}<0.001)$ indicating patterned relationships between items and that factor analysis was appropriate.

Principal components analysis revealed the presence of six components with eigenvalues exceeding 1 explaining $66.3 \%$ of variance. Coefficients $<0.3$ were suppressed. All items had high communalities therefore none were excluded. However, an inspection of the screeplot revealed four main factors which aligned with the conceptual model. Examination of the component matrix identified split loading of items in factor five and six, with the highest loading in other factors. 
A repeated factor analysis specifying four factors, explained $57.5 \%$ of the variance. The Bartlett's test of sphericity (chi-square $=1658.753 p<0.001$ ) showed patterned relationships between the items. The four components had eigenvalues exceeding 1 , explaining $36.18 \%, 9.17 \%, 7.23 \%$ and $4.98 \%$ of the variance respectively (Table 2 ).

The four factors were named according to the underlying construct: 'seeks information' (Factor 1); 'reflects on practice' (Factor 2); 'facilitates shared decision making' (Factor 3) and 'evaluates practice' (Factor 4). For items that were spilt loaded, allocation decisions were made based on the highest loading factor, apart from one item which had a very close split loading and a decision was made on a conceptual basis.

\section{Internal reliability}

The coefficient alpha for the total scale was 0.92 , demonstrating good internal consistency (DeVellis, 2017). Cronbach's alpha coefficient for the subscales ranged from 0.73-0.88 (see Table 2). Following the item analysis, evaluation of construct validity and reliability the tool was named XXXX Assessment of Critical Thinking in Midwifery (CACTiM) - student version. 
Table 2: Item, factor, and subscale analysis summary of the CACTiM (Student version) scale

\begin{tabular}{|c|c|c|c|c|c|c|c|c|c|}
\hline \multirow[t]{2}{*}{ Factor } & \multirow[t]{2}{*}{ Factor title } & \multicolumn{4}{|c|}{ Item Analysis } & \multicolumn{3}{|c|}{ Construct validity (factor analysis) } & \multirow{2}{*}{$\begin{array}{l}\text { Internal } \\
\text { reliability } \\
\text { Cronbach's } \\
\alpha\end{array}$} \\
\hline & & $\begin{array}{l}\text { Number } \\
\text { of Items }\end{array}$ & $\begin{array}{l}\text { Corrected } \\
\text { item total } \\
\text { correlation }\end{array}$ & $\begin{array}{l}\text { Corrected } \\
\text { item sub- } \\
\text { scale } \\
\text { correlation } \\
\text { range }\end{array}$ & $\begin{array}{l}\text { Subscale } \\
\text { - total } \\
\text { correlation }\end{array}$ & Eigenvalue & $\begin{array}{l}\text { \% explained } \\
\text { variance }\end{array}$ & $\begin{array}{l}\text { Loading } \\
\text { range }\end{array}$ & \\
\hline 1 & $\begin{array}{l}\text { Seeks } \\
\text { information }\end{array}$ & 7 & $0.51-0.60$ & $0.45-0.72$ & 0.87 & 9.05 & 36.18 & $0.34-0.78$ & 0.82 \\
\hline 2 & $\begin{array}{l}\text { Reflects on } \\
\text { Practice }\end{array}$ & 7 & $0.55-0.69$ & $0.52-0.78$ & 0.80 & 2.30 & 9.17 & $0.42-0.83$ & 0.87 \\
\hline 3 & $\begin{array}{l}\text { Facilitates } \\
\text { shared decision } \\
\text { making }\end{array}$ & 5 & $0.54-0.67$ & $0.66-0.79$ & 0.76 & 1.80 & 7.23 & $-0.54--0.85$ & 0.88 \\
\hline 4 & $\begin{array}{l}\text { Evaluates } \\
\text { practice }\end{array}$ & 6 & $0.31-0.65$ & $0.34-0.55$ & 0.81 & 1.24 & 4.98 & $0.43-0.69$ & 0.73 \\
\hline
\end{tabular}




\section{CACTIM (student version) scores}

The mean total score for the CACTiM scale was 124.98 ( $S D=12.58)$. The mean item score was 4.99 out of 6 . This high item mean indicated that overall students agreed that their practices reflected a reasonably high level of critical thinking in practice. Table 3 presents a summary of the mean scores and valid percentages for all items. 
Table 3: Student responses on each item and item means

\begin{tabular}{|c|c|c|c|c|c|c|c|}
\hline Factors and items & $\begin{array}{c}\text { Strongly } \\
\text { Disagree } \\
\text { n (\%) }\end{array}$ & $\begin{array}{l}\text { Disagree } \\
\text { n (\%) }\end{array}$ & $\begin{array}{c}\text { Tend to } \\
\text { Disagree } \\
\text { n (\%) }\end{array}$ & $\begin{array}{l}\text { Tend to } \\
\text { Agree } \\
\text { n (\%) }\end{array}$ & $\begin{array}{l}\text { Agree } \\
\text { n (\%) }\end{array}$ & $\begin{array}{l}\text { Strongly } \\
\text { Agree } \\
\text { n (\%) }\end{array}$ & $\begin{array}{l}\text { Item } \\
\text { mean } \\
\text { Score (SD) }\end{array}$ \\
\hline \multicolumn{8}{|l|}{ Factor 1-Seeks Information } \\
\hline I explore multiple solutions to a given situation & & & $8(6.3)$ & $35(27.8)$ & $53(42.1)$ & $30(23.8)$ & $4.8(0.9)$ \\
\hline $\begin{array}{l}\text { If problems arise when caring for the woman I always } \\
\text { try to seek the root cause }\end{array}$ & & & $6(4.8)$ & $29(23.0)$ & $50(39.7)$ & $41(32.5)$ & $5.0(0.9)$ \\
\hline $\begin{array}{l}\text { I liaise and negotiate with colleagues at different } \\
\text { levels about processes to optimise outcomes for the } \\
\text { woman }\end{array}$ & & $2(1.6)$ & $14(11.1)$ & $28(22.2)$ & $46(36.5)$ & $36(28.6)$ & $4.8(1.0)$ \\
\hline $\begin{array}{l}\text { I consult resources (e.g. literature, guidelines, etc.) to } \\
\text { improve care for the woman }\end{array}$ & & & $4(3.2)$ & $33(26.2)$ & $44(34.9)$ & $45(35.7)$ & $5.0(0.9)$ \\
\hline $\begin{array}{l}\text { I seek clarification about interventions that appear } \\
\text { inappropriate or unnecessary }\end{array}$ & & & $3(2.4)$ & $18(14.3)$ & $50(39.7)$ & $55(43.7)$ & $5.3(0.8)$ \\
\hline $\begin{array}{l}\text { Where needed, I negotiate a collaborative } \\
\text { intervention plan with relevant health care providers }\end{array}$ & $1(0.8)$ & $2(1.6)$ & 20 (15.9) & $36(28.6)$ & $44(34.9)$ & $23(18.3)$ & $4.5(1.1)$ \\
\hline $\begin{array}{l}\text { I question the 'unwritten rules' in midwifery practice } \\
\text { that are not evidence-based }\end{array}$ & $1(0.8)$ & $1(0.8)$ & $17(13.5)$ & 40 (31.7) & $43(34.1)$ & $24(19.0)$ & $4.6(1.0)$ \\
\hline Mean Item Score for Factor 1 & & & & & & & 4.85 \\
\hline
\end{tabular}




\begin{tabular}{|c|c|c|c|c|c|c|c|}
\hline Factors and items & $\begin{array}{c}\text { Strongly } \\
\text { Disagree } \\
\text { n (\%) }\end{array}$ & $\begin{array}{l}\text { Disagree } \\
\text { n (\%) }\end{array}$ & $\begin{array}{c}\text { Tend to } \\
\text { Disagree } \\
\text { n (\%) }\end{array}$ & $\begin{array}{l}\text { Tend to } \\
\text { Agree } \\
\text { n (\%) }\end{array}$ & $\begin{array}{l}\text { Agree } \\
\text { n (\%) }\end{array}$ & $\begin{array}{c}\text { Strongly } \\
\text { Agree } \\
\text { n (\%) }\end{array}$ & $\begin{array}{l}\text { Item } \\
\text { mean } \\
\text { Score (SD) }\end{array}$ \\
\hline \multicolumn{8}{|l|}{ Factor 2 - Reflects on Practice } \\
\hline $\begin{array}{l}\text { I continually analyse my own strengths and } \\
\text { limitations in skills, knowledge and experience }\end{array}$ & & & $1(0.8)$ & $18(14.3)$ & $35(27.8)$ & $72(57.1)$ & $5.4(0.8)$ \\
\hline $\begin{array}{l}\text { I evaluate my own practice and its effect on the } \\
\text { woman and others }\end{array}$ & & & $1(0.8)$ & $19(15.1)$ & $47(37.3)$ & $59(46.8)$ & $5.3(0.8)$ \\
\hline $\begin{array}{l}\text { I address my own limitations in skills, knowledge and } \\
\text { experience }\end{array}$ & & & & 15 (11.9) & $44(34.9)$ & $67(53.2)$ & $5.4(0.7)$ \\
\hline $\begin{array}{l}\text { I adjust my own practice based on feedback from the } \\
\text { woman and others }\end{array}$ & & & & $10(7.9)$ & $51(40.5)$ & $65(51.6)$ & $5.4(0.6)$ \\
\hline $\begin{array}{l}\text { I can recognise non-evidence based or non- woman } \\
\text { centred practice by self and others }\end{array}$ & & & $4(3.2)$ & $17(13.5)$ & $46(36.5)$ & $59(46.8)$ & $5.3(0.8)$ \\
\hline $\begin{array}{l}\text { I recognise my own attitudes, biases and values and } \\
\text { their potential impact on practice }\end{array}$ & & & $2(1.6)$ & $12(9.3)$ & $48(38.1)$ & $64(50.8)$ & $5.4(0.7)$ \\
\hline $\begin{array}{l}\text { I debrief with a professional colleague following } \\
\text { complex situations to improve my practice }\end{array}$ & & $4(3.2)$ & $3(2.4)$ & $13(10.3)$ & $30(23.8)$ & $76(60.3)$ & $5.4(1.0)$ \\
\hline Mean Item Score for Factor 2 & & & & & & & 5.37 \\
\hline
\end{tabular}




\begin{tabular}{|c|c|c|c|c|c|c|c|}
\hline Factors and items & $\begin{array}{c}\text { Strongly } \\
\text { Disagree } \\
\text { n (\%) }\end{array}$ & $\begin{array}{c}\text { Disagree } \\
\text { n (\%) }\end{array}$ & $\begin{array}{c}\text { Tend to } \\
\text { Disagree } \\
\text { n (\%) }\end{array}$ & $\begin{array}{l}\text { Tend to } \\
\text { Agree } \\
\text { n (\%) }\end{array}$ & $\begin{array}{l}\text { Agree } \\
\text { n (\%) }\end{array}$ & $\begin{array}{c}\text { Strongly } \\
\text { Agree } \\
\text { n (\%) }\end{array}$ & $\begin{array}{l}\text { Item } \\
\text { mean } \\
\text { Score (SD) }\end{array}$ \\
\hline \multicolumn{8}{|l|}{ Factor 3 - Facilitates Shared Decision Making } \\
\hline $\begin{array}{l}\text { I sequence care and education to meet the individual } \\
\text { needs of the woman }\end{array}$ & & & & $17(13.5)$ & $50(39.7)$ & $59(46.8)$ & $5.3(0.7)$ \\
\hline $\begin{array}{l}\text { I choose relevant literature and education strategies } \\
\text { to facilitate the woman's decision making }\end{array}$ & & $1(0.8)$ & $2(1.6)$ & $28(22.2)$ & $52(41.3)$ & $43(34.1)$ & $5.06(0.8)$ \\
\hline $\begin{array}{l}\text { I explore the woman's preferences of care and plan } \\
\text { care accordingly }\end{array}$ & & & & $12(9.5)$ & $46(36.5)$ & $68(54.0)$ & $5.44(0.7)$ \\
\hline $\begin{array}{l}\text { I share relevant evidence and clinical guidelines } \\
\text { related to the woman's individual choices }\end{array}$ & & & $4(3.2)$ & $27(21.4)$ & $55(43.7)$ & 40 (31.7) & $5.0(0.8)$ \\
\hline $\begin{array}{l}\text { I use evidence to plan care according to the woman's } \\
\text { individual circumstances }\end{array}$ & & & $2(1.6)$ & $24(19.0)$ & $63(50.0)$ & $37(29.4)$ & $5.1(0.7)$ \\
\hline \multicolumn{8}{|l|}{ Mean Item Score for Factor 3} \\
\hline
\end{tabular}




\begin{tabular}{|c|c|c|c|c|c|c|c|}
\hline Factors and items & $\begin{array}{c}\text { Strongly } \\
\text { Disagree } \\
\text { n (\%) }\end{array}$ & $\begin{array}{c}\text { Disagree } \\
\text { n (\%) }\end{array}$ & $\begin{array}{c}\text { Tend to } \\
\text { Disagree } \\
\text { n (\%) }\end{array}$ & $\begin{array}{l}\text { Tend to } \\
\text { Agree } \\
\text { n (\%) }\end{array}$ & $\begin{array}{l}\text { Agree } \\
\text { n (\%) }\end{array}$ & $\begin{array}{c}\text { Strongly } \\
\text { Agree } \\
\text { n (\%) }\end{array}$ & $\begin{array}{l}\text { Item } \\
\text { mean } \\
\text { Score (SD) }\end{array}$ \\
\hline \multicolumn{8}{|l|}{ Factor 4- Evaluates Practice } \\
\hline $\begin{array}{l}\text { I often instinctively know what type of care is right for } \\
\text { the woman }\end{array}$ & & $5(4.0)$ & $22(17.5)$ & $46(36.5)$ & $40(31.7)$ & $13(10.3)$ & $4.3(1.0)$ \\
\hline $\begin{array}{l}\text { I apply knowledge from past experiences to present } \\
\text { situations }\end{array}$ & & & $5(4.0)$ & $21(16.7)$ & $55(43.7)$ & 45 (35.7) & $5.1(0.8)$ \\
\hline $\begin{array}{l}\text { I identify organisational/service improvement } \\
\text { opportunities }\end{array}$ & $1(0.8)$ & $2(1.6)$ & $21(16.7)$ & $37(29.4)$ & 49 (38.9) & $16(12.7)$ & $4.4(1.0)$ \\
\hline $\begin{array}{l}\text { I voice my concerns about non-evidence based or } \\
\text { non-woman centred practices by self and others }\end{array}$ & & $4(3.2)$ & $12(9.5)$ & $47(37.3)$ & $48(38.1)$ & 15 (11.9) & $4.5(0.9)$ \\
\hline $\begin{array}{l}\text { I initiate professional dialogue around midwifery } \\
\text { practice }\end{array}$ & & $2(1.6)$ & $7(5.6)$ & $42(33.3)$ & $57(45.2)$ & $18(14.3)$ & $4.7(0.9)$ \\
\hline $\begin{array}{l}\text { I can provide the rationale for following (or departing } \\
\text { from) established guidelines and policies }\end{array}$ & $1(0.8)$ & $2(1.6)$ & 15 (11.9) & $49(38.9)$ & $46(36.5)$ & $13(10.3)$ & $4.4(0.9)$ \\
\hline Mean Score for Factor 4 & & & & & & & 4.58 \\
\hline
\end{tabular}




\section{Factor 1: Seeks information}

This seven item factor had good internal reliability (Cronbach's alpha .82). The factor total mean score was $34.0(S D=4.6)$ out of a possible 42 . The item mean for this factor was 4.85. An analysis of the relationship between the subscale information seeking and the CACTiM (Student version) revealed a strong positive correlation between this subscale and the total scale $(r=.87, p<.001)$.

Factor 2: Reflects on practice

This seven item factor had good internal reliability (Cronbach's alpha .87). The factor total mean score was $37.6(S D=4.1)$ out of a possible 42 . This factor had the highest mean item score of 5.37. Correlation between this subscale and the total scale was strong $(r=.80, p<.001)$.

Factor 3: Facilitates shared decision making

This five item subscale had good internal reliability (Cronbach's alpha .88). The factor total mean score was 26.0 (SD = 3.1) out of a possible 30. The item mean for this factor was 5.19. A positive correlation was found between this subscale and the total scale $(r=.76, p<.001)$.

\section{Factor 4: Evaluates practice}

This six item subscale demonstrated lower internal reliability (Cronbach's alpha .73). Although values above 0.8 are preferred to ascertain reliability, values greater than 0.70 are an acceptable lower boundary for alpha coefficients (DeVellis, 2017, Nunnally, 1978). The factor total mean score was $27.5(\mathrm{SD}=3.7)$ out of a possible 36. The item mean was 4.57. A strong positive relationship was demonstrated between this subscale and the total scale $(r=.81, p<.001)$.

\section{Motivated Strategies for Learning Questionnaire}

The mean total score for the 5 items in the MSLQ critical thinking sub-scale was 21.04 (SD =4.21). The mean item score was 4.2. This item mean was lower than those within each CACTiM subscale. This may indicate that students do not apply critical thinking skills in their learning to the same degree they apply these skills to 
midwifery practice. Table 4 presents a summary of the mean scores and valid percentages for all items of the MSLQ.

The relationship between the MSLQ and the CACTiM (Student version) revealed a medium positive correlation between the total scores of both scales $(r=.32, p<.001)$. According to Cohen (1988) an r value between .30 and .49 indicates a medium effect. 
Table 4: Proportion of student responses on each item and item mean for MSLQ

\begin{tabular}{|c|c|c|c|c|c|c|c|}
\hline Factors and items & $\begin{array}{c}\text { Strongly } \\
\text { Disagree } \\
n(\%)\end{array}$ & $\begin{array}{c}\text { Disagree } \\
\text { n (\%) }\end{array}$ & $\begin{array}{c}\text { Tend to } \\
\text { Disagree } \\
\text { n (\%) }\end{array}$ & $\begin{array}{l}\text { Tend to } \\
\text { Agree } \\
\text { n (\%) }\end{array}$ & $\begin{array}{l}\text { Agree } \\
\text { n (\%) }\end{array}$ & $\begin{array}{l}\text { Strongly } \\
\text { Agree } \\
\text { n (\%) }\end{array}$ & $\begin{array}{l}\text { Mean } \\
\text { Score (SD) }\end{array}$ \\
\hline \multicolumn{8}{|l|}{$\begin{array}{l}\text { Motivated Strategies for Learning Questionnaire } \\
\text { I often find myself questioning things I hear or read in } \\
\text { this program to decide if I find them convincing }\end{array}$} \\
\hline $\begin{array}{l}\text { When a theory, interpretation, or conclusion is } \\
\text { presented in class or in the readings, I try to decide if } \\
\text { there is good supporting evidence }\end{array}$ & $1(0.8)$ & $7(5.6)$ & 15 (11.9) & 55 (43.7) & $38(30.2)$ & $10(7.9)$ & $4.21(1.0)$ \\
\hline $\begin{array}{l}\text { I treat the course material as a starting point and try } \\
\text { to develop my own ideas about it. }\end{array}$ & $1(0.8)$ & $6(4.8)$ & $12(9.5)$ & 40 (31.7) & $48(38.1)$ & $19(15.1)$ & $4.47(1.1)$ \\
\hline $\begin{array}{l}\text { I try to play around with ideas of my own related to } \\
\text { what I am learning in this program. }\end{array}$ & $1(0.8)$ & $6(4.8)$ & $7(5.6)$ & $55(43.7)$ & $35(27.8)$ & $22(17.5)$ & $4.5(1.0)$ \\
\hline $\begin{array}{l}\text { Whenever I read or hear an assertion or conclusion in } \\
\text { this program, I think about possible alternatives. }\end{array}$ & $1(0.8)$ & $9(7.1)$ & $19(15.1)$ & $52(41.3)$ & $36(28.6)$ & $9(7.1)$ & $4.11(1.4)$ \\
\hline Mean Score for MSLQ & & & & & & & 4.20 \\
\hline
\end{tabular}




\section{Discussion}

The CACTiM (Student version) aimed to measure students' self-appraisal of their critical thinking skills in practice and was found to have good reliability and validity. Factor analysis revealed four factors which comprised of: seeks information, reflects on practice, facilitates shared decision making and evaluates practice. The CACTiM sub-scales were found to be internally reliable and theoretically and practically coherent.

\section{Seeks information}

The items within this factor related to the gathering of data to inform clinical decisions. Five of the seven items involved collaboration with other health professionals through liaison, negotiation, consultation, clarification and questioning. These items acknowledge that midwifery care is not provided in isolation but is delivered within a collaborative framework that not only involves the woman and her family but other health professionals. The development of collaborative collegial relationships with other health professionals is an essential skill to optimise outcomes for women (ANMC, 2006; Skinner and Foureur, 2010). Successful collaboration involves open communication, cooperation, consultation and joint decision making to enable appropriate referral and ensure effective and safe care is provided (Cragin and Kennedy, 2006; NMBA, 2007). Sound collaborative practice is particularly important between midwives and obstetricians when complexities arise and a team approach to care is required (Skinner and Foureur, 2010; Downe et al., 2010). Yet tension due to differing opinions may exist and present a myriad of challenges affecting critical decisions related to care (Watson et al., 2012; Van Helmond et al., 2015). It is therefore crucial for student midwives to develop collaborative skills and respectful professional relationships to optimise care provided to women and their families.

One item involved the questioning of others' practices or 'unwritten rules' that often hinder evidence-based care. The use of 'unwritten rules' to guide midwifery practice is problematic. Generally, these rules have little scientific basis, are based on tradition rather than current evidence, and are often practiced by senior midwives (Hunter, 2005). Unwritten rules are founded on institutional etiquette and can quickly become the cultural norm of the organisation translated through individual 
preferences of the midwife (Hunter, 2005). Some midwives unquestioningly accept the unwritten rules and are often unaware their practice is out of date and ritualistic (Bluff, 2001; Cluett and Bluff, 2006). These rituals are often imposed on peers and students, and contribute to less than optimal care for women. The questioning of 'unwritten rules' and commitment to quality are vital critical thinking processes to ensure appropriate, evidence-based decisions related to midwifery care.

\section{Reflects on practice}

The items within this factor represent the student's skills and abilities to reflect on, and analyse their own practice. These items assessed students' capacity to analyse their own practice, identify strengths and weaknesses and address these, consider the impact of current practices on others, and value reflection and debriefing with colleagues.

Within the consensus definition of critical thinking in nursing, reflection is considered an essential core component. Scheffer and Rubenfeld (2000) defined reflection as 'contemplation upon a subject, especially one's assumptions and thinking for the purposes of deeper understanding and self-evaluation' (p358). The items in this factor were designed to capture reflection in and on practice. Quality clinical placements provide students with a rich environment to develop critical thinking skills through reflection (Kennison, 2006). It could be argued that the development of critical thinking is not possible without reflection. Reflection promotes the likelihood of students improving their own thinking and action, and is often referred to as the highest level of metacognition within critical thinking (Facione, 2015).

Responses on 'Reflects on Practice' items scored the highest mean within the total scale. This high mean may be a direct consequence of learning and teaching strategies used in the Bachelor of Midwifery programme that focus on the development of reflective skills (Bass et al., 2016). Students are required to complete at least two written reflections per semester using a structured reflective framework. The Holistic Reflection Model has six integrated, inter-dependant stages designed to promote detailed critical reflection at a deeper personal and holistic level (Bass et al., 2017).

Facilitates shared decision making. 
This factor comprises of items unique to the profession of midwifery. Items relate to the ability of the midwife to explore and share evidence, clinical guidelines, and options of care with women to facilitate informed decision making. The concept of shared decision making is supported by the International Confederation of Midwives statement on Philosophy and Model Midwifery Care (ICM, 2014). Midwives are recognised as partners in care who promote the woman's self-determination, provide appropriate information and advice to facilitate participation, and enhance informed decision making (ICM, 2014). Shared decision making acknowledges the expertise that both parties bring to the discussion, including the midwife's knowledge of evidence, experience, and skills, as well as the woman's preferences, selfknowledge and experience (Young, 2012). This negotiated partnership and shared decision making adds a layer of complexity to midwifery decision making in practice.

Critical thinking can be viewed as a purposeful activity which enables effective decision making. Critical thinking involves a process of analysis, interpretation, evaluation, inference, explanation, and reflection (Facione, 1990; Hendricson, et al., 2006). However, critical thinking in midwifery practice requires an additional element that incorporates the role of the midwife in facilitating shared decision making with childbearing women that then informs practice. Midwifery decision making is holistic and woman centred and requires considerable interpersonal negotiation skills and consideration of the woman's desires and choices (Davis-Floyd, 2004; Jefford et al., 2010a).

\section{Evaluates practice}

Items within this factor relate to the student's ability to evaluate their own and others' practice in order to identify possible practice improvements. This factor scored the lowest mean, perhaps indicating that the items within this factor require the high critical thinking skills that develop over time. The lowest scoring item 'I often instinctively know what type of care is right for the woman' was designed to measure the critical thinking concept of intuition. Intuition is included within the nursing consensus definition of critical thinking as an 'insight sense of knowing without a conscious use of reason' (Scheffer and Rubenfeld, 2000, p358).

Incorporation of intuition within critical thinking is well suited to the midwifery paradigm which embraces a variety of knowledges to holistically make clinical 
decisions and recognise the significance of childbirth as a life event (Siddiqui, 2005). Using intuition in decision making relies on an exquisite sensitivity to pattern recognition and heuristics based on prior experience (Steinhauer, 2015). When using intuition, rapid and unconscious judgments are made based on a variety of cues and past experiences (Steinhauer, 2015; Geraghty, 2015). Applying knowledge from past experiences is a recognised core component of critical thinking (Facione and Facione, 1996). The use of intuition in decision making is in the domain of an 'expert' who no longer consciously relies on formal analytical judgement processes, thereby enhancing clinical judgment and making fast decisions (Benner, 2001; Jefford et al., 2010b). Considering the high level of expertise required in intuition, the lower average mean for this item by students could be expected.

Another low scoring item within this subscale involved the identification of organisational/service improvements. This item was designed to measure students' ability to question and identify policy, practice or organisational improvements. This skill may be challenging for students as they often attempt to conform to the expectations and norms of the organisation (Begley, 2001). However, the identification of quality improvements is a vital component of safe midwifery care and a core component of critical thinking (Scheffer and Rubenfield, 2000; Cronenwett, et al.,2007). The introduction of an assessment item within curricula to encourage students to identify practice or organisation improvements may be useful to further develop these skills.

Implications for education, research, and practice.

The CACTiM (Student version) is the first instrument specifically designed to enable students to appraise their critical thinking in midwifery practice. The tool has various possible uses and benefits. The items within the tool endeavour to reflect the multiple elements of critical thinking in midwifery practice. Thus, the simple act of students completing this tool affords them the opportunity to reflect on their own practice as well as providing explicit examples of critical thinking expected in midwifery practice. This examination of their own practice and increased awareness of the application of critical thinking skills in practice has the potential to not only improve critical thinking skills but also promote greater autonomy over their own learning. The elements of the tool may also be useful to guide midwifery lecturers in 
the design of learning and assessment opportunities that explicitly assist students' critical thinking development.

This tool could be used in the longitudinal measurement of critical thinking development throughout a midwifery education programme or as a single measure for midwifery graduates and midwives in practice. Further use of the tool could include tracking first year students' development of critical thinking through the degree. Currently, the focus of clinical assessment in most pre-registration programs is largely on the attainment and assessment of technical skill development (Lake and Mclnnes, 2012; ANMC, 2014). The CACTiM (Student version) may facilitate and measure cognitive skill development in practice, identify areas of development and enable students and their lecturers to examine the transformation of these skills over time. The tool could also be used to test the effectiveness of teaching strategies and preparedness of graduates for practice.

In this study reliability and validity was established for the CACTiM (Student version) however, further research is required. The tool needs to be validated with a larger cohort of students from a variety of universities undertaking different curricula and working across different clinical environments. Further validation would facilitate comparisons within national and international contexts guiding the development of curricula and teaching strategies.

\section{Limitations}

Although a response rate of $76.8 \%$ was considered adequate, students less interested/capable in critical thinking may not have participated. It may be that higher performing students felt more comfortable assessing their own critical thinking skills. It is also acknowledged that the sample was relatively homogenous with students recruited from one Australian University. Testing with large diverse samples of students is warranted. Around $30 \%$ of students already possessed a Bachelor's Degree which may have contributed to an inflated overall mean CACTiM total score. However, as the tool is specifically designed to measure critical thinking in midwifery practice, it is unknown whether critical thinking skills gained in a different degree influenced responses on this tool, and requires further investigation. 
It was challenging to establish concurrent validity of this new tool due to the dearth of tools available that measure critical thinking in midwifery practice. An attempt was made to establish concurrent validity through the inclusion of 5 questions related to critical thinking from a subscale of the MSLQ. Although both the MSLQ sub-scale and the CACTIM (Student version) are both designed to measure critical thinking the low correlation between the two scales was not surprising. The MSLQ measures students' critical thinking in their approach to learning, whereas the CACTiM scale is designed to measure the application of critical thinking skills in practice.

Although the use of tools by students to self-assess their own progress and learning is sound pedagogical practice, self-report may contribute to response bias. A more robust approach could include the collection of multiple forms of data (such as independent observation; feedback from women) to improve validity of the tool. Triangulation of data collected from this tool in conjunction with a similar tool that measures preceptors/mentors perceptions of students' critical thinking skills in practice is recommended. Further comparison of this data with students' accounts of their clinical practice through reflections would further improve this.

Even though a rigorous process was used to develop items, CACTiM may not fully encompass all aspects of critical thinking in midwifery practice. Further use of the tool with diverse samples is recommended.

\section{Conclusion}

Critical thinking involves purposeful activity which enhances the effectiveness of decision making. Decision making in midwifery is a complex process that shapes and underpins clinical practice and influences the quality of care. Critical thinking is a fundamental skill for students to develop, facilitating their transition to competent autonomous midwifery practice. The measurement of critical thinking skill development should be embedded within midwifery curricula. Utilising a selfassessment tool can cultivate essential professional skills including critical awareness, decision making, critical thinking and enhance learning. This pilot study indicates that the CACTiM (Student version) is a reliable and valid measure of critical thinking skills in midwifery practice. This self-assessment tool could be utilised over 
time to measure critical thinking skill development and facilitate feedback on these skills. While the CACTIM measures students' perception of their critical thinking skills, a multimethod approach including triangulation of data would provide a more rigorous approach to measuring critical thinking in midwifery practice. 


\section{References}

Australian College of Midwives, 2011. Philosophy of the Midwife.

http://www.midwives.org.au/scripts/cgiip.exe/Wservice=MIDW/ccms.r?pageid=10019

\section{Australian Qualifications Framework Council, 2013. Australian Qualifications Framework} http://www.agf.edu.au/wp-content/uploads/2013/05/AQF-2nd-Edition-January2013.pdf

Australian Nursing and Midwifery Council, 2006. National Competency Standards for the Midwife. Retrieved from http://www.nursingmidwiferyboard.gov.au/CodesGuidelines-Statements/Codes-Guidelines.aspx\#competencystandards

Australian Nursing and Midwifery Council, 2014. Midwife: Accreditation Standards (Canberra). Retrieved from http://www.anmac.org.au/sites/default/files/documents/ANMAC Midwife Accreditatio n Standards 2014.pdf

Bass, J., Walters, C., Toohill, J., Sidebotham, M., 2016. Promoting retention, enabling success: Discovering the potential of student support circles. Nurse Education in Practice 20, 109-116. http://dx.doi.org/10.1016/j.nepr.2016.07.002

Bass,J., Fenwick,J., Sidebotham.M., 2017. Development of a model of holistic reflection to facilitate transformative learning in student midwives. Women and Birth, S1871-5192 http://dx.doi.org/10.1016/i.wombi.2017.02.010

Begley, C.M., 2001. 'Giving midwifery care': student midwives' views of their working role. Midwifery, 17, 24-34.

Benner, P., 2001. From novice to expert: excellence and power in clinical nursing practice, Prentice Hall Health, New Jersey.

Bluff, R., 2001. Teaching and learning in the context of clinical practice: The midwife as a role model (Unpublished doctoral dissertation). Bournemouth University, United Kingdom.

Carter, A.G. Creedy, D. K., Sidebotham, M., 2015. Evaluation of tools used to measure critical thinking development in nursing and midwifery undergraduate students: A systematic review. Nurse Education Today 35 (7), 864-874. http://dx.doi.org/10.1016/j.nedt.2015.02.023

Carter, A. G., Creedy, D.K., Sidebotham, M., 2016. Efficacy of teaching methods used to develop critical thinking in nursing and midwifery undergraduate students: A systematic review of the literature. Nurse Education Today 40, 209-218. http://dx.doi.org /10.1016/j.nedt.2016.03.010

Cohen, J.W., 1988. Statistical power analysis for the behavioural sciences ( $2^{\text {nd }}$ ed.). Lawrence Erlbaum Associates, Hillsdale, NJ. 
Cragin, L., Kennedy, H. P., 2006. Linking obstetric and midwifery practice with optimal outcomes. Journal of Obstetric, Gynecologic and Neonatal Nursing Nursing 35 (6), 779-785.

Credé, M., Phillips, A.L., 2011. A Meta-analytic review of the Motivated Strategies for Learning Questionnaire. Learning and Individual Differences, 21 (4), 337-346.

Cronenwett, L., Sherwood, G., Barnsteiner, J., Disch, J., Johnson, J., Mitchell, P., TaylorSullivan, D. Warren, J., 2007. Quality and safety education for nurses. Nursing Outlook 55 (3), 122-131.

Cluett, E., Bluff, R., 2006. From practice to research. In: Cluett, E., Bluff, R., (Eds) Principles of Practice and Research in Midwifery ( $2^{\text {nd }} \mathrm{Ed}$.)

Churchill Livingstone Elsevie, New York. pp. 13-29.

Davis-Floyd R., 2004. Introduction. In: Fyre, A.. (Eds.). Holistic Midwifery: A Comprehensive Textbook for Midwives in Homebirth Practice. Labrys Press, Portland, USA. pp. 1-8.

Dearnley, C. A., Meddings, F. S., 2007. Student self-assessment and its impact on learning - A pilot study. Nurse Education Today 27, 333-340

DeVellis, R. F., 2017. Scale development: Theory and applications (4 ${ }^{\text {th }}$ ed). Sage, Thousand Oaks, California.

Downe, S., Finlayson, K., Fleming, A., 2010. Creating a collaborative culture in maternity care. Journal of Midwifery \& Women's Health 55, 250-254.

Facione, P.A., 1990. Critical Thinking: A Statement of Expert Consensus for Purposes of Educational Assessment and Instruction, Executive Summary: "The Delphi Report". The Californian Academic Press, CA (Retrieved from http://assessment.aas.duke.edu/documents/Delphi_Report.pdf)

Facione, N. C., Facione, P. A. 1996. Externalizing the critical thinking in knowledge development and clinical judgement. Nursing Outlook 44, 129-136.

Facione, P. A., 2015 Critical thinking: What it is and why it counts. Insight Assessment. Retrieved from http://www.insightassessment.com/Resources/Critical-ThinkingWhat-It-Is-and-Why-It-Counts/Critical-Thinking-What-It-Is-and-Why-It-Counts-PDF

Gable, R. K., Wolf, J. W., 1993. Instrument development in the affective domain: Measuring attitudes and values in corporate and school settings. Kluwer Academic, Boston, MA.

Garcia Duncan, T., McKeachie, W. J., 2005. The making of the Motivated Strategies for Learning Questionnaire. Educational Psychologist 40 (2), 117-128.

Geraghty, S., 2015. Keeping the shining roads open: intuition in midwifery practice. The Practising Midwife 18 (10), 42-45.

Gorsuch, R. L., 1983. Factor Analysis (2nd ed.). Lawrence Erlbaum Associates, Hillsdale, NJ. 
Grant, J. S., Davis, L. L., 1997. Selection and use of content experts for instrument development. Research in Nursing \& Health 20, 269-274.

Hatcher, L., 1994. A Step-by-Step Approach to Using the SAS® System for Factor Analysis and Structural Equation Modeling. SAS Institute, Inc., Cary, N.C.

Hendricson, W.D., Andrieu, S.C., Chadwick, G., Chmar, J.E., Cole, J.R., George, M.C., Glickman, G.N., Glover, J.F., Goldberg, J.S. Haden, K., Meyerowitz, C., Neumann, L., Pyle, M., Tedesco, L.A. Valachovic, R.W., Weaver, R.G., Winder, R.L., Young, S.K.,. Kalkwarf, K.L., 2006. Educational strategies associated with development of problem-solving, critical thinking, and self-directed learning. Journal of Dental Education 70, 925-936.

Hunter, B., 2005. Emotion work and boundary maintenance in hospital-based midwifery. Midwifery 21, 253-266.

International Confederation of Midwives. 2014. Philosophy and Model of Midwifery Care, The Hague. Retrieved from http://www.internationalmidwives.org/assets/uploads/documents/CoreDocuments/CD 2005_001\%20V2014\%20ENG\%20Philosophy\%20and\%20model\%20of\%20midwifer y\%20care.pdf

Jefford, E., Fahy, K., Sundin D., 2010a. Decision-making theories and their usefulness to the midwifery profession both in terms of midwifery practice and the education of midwives. International Journal of Nursing Practice 17, 246-253.

Jefford, E, Fahy, K., Sundin, D., 2010b. A review of the literature: Midwifery decisionmaking and birth', Women and Birth 23 (4), 127-134. http://dx.doi.org/10.1016/j.wombi.2010.02.001

Kaiser, H., 1974. An index of factorial simplicity. Psychometrika 39, 31-6.

Kennison, M. M., 2006. The evaluation of students' reflective writing for evidence of critical thinking. Nursing Education Perspectives 27 (5), 269-273.

Kitson-Reynolds, E., Rogers, J., 2013. Decision making and supervision for third-year student midwives. British Journal of Midwifery 19 (2), 125-129.

Lake, S., Mclnnes, R. J., 2012. Exploring cognitive skill development in midwifery education. Nurse Education in Practice 12, 264-268.

Lynn, M. R., 1986. Determination and quantification of content validity. Nursing Research, $35(6), 382$.

McAllister, M., 2005. Transformative teaching in nursing education: leading by example. Collegian 12 (2), 11-16.

McAllister, M., Tower, M. Walker, R., 2007. Gentle interruptions: Transformative approaches to clinical teaching. Journal of Nursing Education 46 (7), 304-312. 
Mould, M. R., Bray, K. K., Gadbury-Amyot, C. C., 2011. Student self-assessment in dental hygiene education: A cornerstone of critical thinking and problem-solving. Journal of Dental Education 75 (8), 1061-1072.

Nunnally, J. C., 1978. Psychometric theory (2nd ed.) New York: McGraw-Hill.

Nursing and Midwifery Board of Australia. 2007. A national framework for the development of decision-making tools for nursing and midwifery practice. Retrieved from http://www.nursingmidwiferyboard.gov.au/Codes-GuidelinesStatements/Frameworks.aspx

Office of Educational Research and Improvement/Department of Education. 1991. A Manual for the Use of the Motivated Strategies for Learning Questionnaire (MSLQ). National Center for Research to Improve Postsecondary Teaching and Learning, Ann Arbor, MI.

Raosoft, 2004. Sample size calculator. Retrieved from http://www.raosoft.com/samplesize.html.

Renfrew, M., McFadden, A., Bastos, M., Campbell, J., Channon, A., Cheung, N., Silva, D., Downe, S., Kennedy, H., Malata, A., McCormick, F., Wick, L., Declercq, E., 2014. Midwifery and quality care: findings from a new evidence-informed framework for maternal and newborn care. The Lancet. http://dx.doi.org/10.1016/S0140$\underline{6736(14) 60789-3}$

Sadler, R., 2005. Interpretations of criteria-based assessment and grading in higher education. Assessment \& Evaluation in Higher Education 30, 175-194.

Scheffer, B. K., Rubenfeld, M. G., 2000. A consensus statement on critical thinking in nursing. Journal of Nursing Education 39 (8), 352-359.

Scholes, J., Endacott, R., Biro, M., Bulle, B., Cooper, S., Miles, M., Gilmour, C., Buykx, P., Kinsman, L., Boland, R., Jones, J., Zaidi, F., 2012. Clinical decision-making: midwifery students' recognition of, and response to, postpartum haemorrhage in the simulation environment. BMC Pregnancy and Childbirth 12, 19.

Siddiqui, J. 2005. The role of knowledge in midwifery decision making. In: Raynor MD, Marshall JE and Sullivan A (Eds.). Decision making in midwifery practice. Churchill Livingstone, London. Pp. 23-36.

Skinner, J. P., Foureur, M. 2010. Consultation, referral, and collaboration between midwives and obstetricians: lessons from New Zealand, Journal of Midwifery and Women's Health 55 (1), 29-37.

Steinhauer, S., 2015. Decision making in midwifery: rationality and intuition. The Practising Midwife 18 (4), 14-18.

Thompson C, Dowding D., 2002. Decision making and judgment in nursing - an introduction. In: Thompson C, Dowding D, (Eds.), Clinical Decision Making and Judgment in Nursing, Churchill Livingstone, London. pp 1-20. 
Van Helmond, I., Korstjens, I., Mesman, J., Nieuwenhuijze, M., Horstman, K., Scheepers, H., Spaanderman, M., Keulen, J., de Vries, R., 2015. What Makes for Good Collaboration and Communication in Maternity Care? A Scoping Study. International Journal of Childbirth 5, 210-223. https://doi.org/10.1891/2156-5287.5.4.210

Walz, C. F., Strickland, O., Lenz, E., 1991. Measurement in Nursing Research (Vol. 2). F.A. Davis, Philadelphia.

Watson, B.M., Heatley, M.L., Kruske, S.G., Gallois, C., 2012. An empirical investigation into beliefs about collaborative practice among maternity care providers. Australian Health Review 36 (12), 470459.

Young, N., 2012. An exploration of clinical decision-making among students and newly qualified midwives, Midwifery 28, 824-830. 